International Journal of Biological Research, $2(2)(2014) 134-139$
International Journal of Biological Research
Journal home page: $\begin{gathered}\text { www.sciencepubco.com/index.php/IJBR } \\ \text { doi: } 10.14419 / \text { ijbr.v2i2.2537 } \\ \text { Research Paper }\end{gathered}$

\title{
Molecular identification and amylolytic potential of a thermophilic bacteria species from refuse dump in Ile-Ife, Nigeria
}

\author{
Omoboye Olumide Owolabi ${ }^{1}$, Bakare Mufutau Kolawole ${ }^{1 *}$, Adewale Isaac Olusanjo ${ }^{2}$, Oyedeji Olaoluwa ${ }^{1}$ \\ ${ }^{1}$ Department of Microbiology, Obafemi Awolowo University, Ile-Ife, Nigeria. 220005 \\ ${ }^{2}$ Departments of Biochemistry, Obafemi Awolowo University, Ile-Ife, Nigeria. 220005 \\ *Corresponding author E-mail: mufubakare@yahoo.com
}

\begin{abstract}
Molecular identification and amylolytic potential of a thermophilic bacterium species isolated from refuse dump was investigated. Bacterial isolates were identified by morphological and biochemical characterization while amylolytic bacterium of interest was identified by molecular analysis using 16S rRNA gene sequencing. The bacterium with the highest $\alpha$-amylase activity was selected for enzyme production. The optimal conditions for $\alpha$-amylase secretion were determined by varying the $\mathrm{pH}$, temperature, percentage soluble starch, nitrogen sources and carbon sources. The isolated and identified bacteria were Bacillus alvei (40\%) Bacillus licheniformis (40\%) and Bacillus brevis (20\%) while Bacillus licheniformis RD24 was identified by $16 \mathrm{~S}$ rRNA gene sequencing. The peak of amylase production was at $20 \mathrm{~h}$ of incubation $(925 \mu \mathrm{g} / \mathrm{ml} / \mathrm{min})$. The optimum $\mathrm{pH}$ and temperature for the enzyme production were 7 and $45^{\circ} \mathrm{C}$ respectively. Enzyme production medium with $1 \%$ starch gave highest enzyme activity of $102 \pm 5.3 \mu \mathrm{g} / \mathrm{ml} / \mathrm{min}$. Peptone gave an enzyme activity of $165 \pm 8.97 \mu \mathrm{g} / \mathrm{ml} / \mathrm{min}$ and yeast extract gave $52.26 \pm 2.86 \mu \mathrm{g} / \mathrm{ml} / \mathrm{min}$. Of the raw starches, cassava flour gave the highest specific activity of $72 \pm 0.07$ Units/mg proteins, while sorghum starch gave the lowest specific activity of $5 \pm 1.52$ Units/mg proteins. The study concluded that starch-rich household waste can be employed for amylase production using Bacillus licheniformis RD24.
\end{abstract}

Keywords: Alpha Amylase, Bacillus Species, Optimum, Soluble Starch, Thermophilic.

\section{Introduction}

Starch production in the earth was estimated to be in the order of $2.0 \times 10^{10}$ tonnes/year, which corresponds to about $80 \%$ of total food production worldwide (Sarikaya et al., 2000). Enzymes are among the most important products acquired for human needs in the areas of industrial, environmental and food biotechnology through microbial sources. Alpha amylase is a hydrolytic enzyme and in recent years, interest in its microbial production has increased dramatically due to its wide spread use in food, textile, baking and detergent industries (Asgher et al., 2007). Amylases are hydrolases that function by the breakdown or hydrolysis of starch into reducing fermentable sugars, mainly maltose and reducing non-fermentable or slowly fermentable dextrins (Oyeleke et al., 2010). Among various extracellular enzymes, $\alpha$-amylase ranks first in terms of commercial exploitation (Babu and Satyanarayana, 1993) and accounts for $12 \%$ of the sales value of the world market (Baysal et al., 2003). Spectrum of applications of $\alpha$-amylase has widened in many sectors such as clinical, medicinal and analytical chemistry. Besides their use in starch saccharification, they also find applications in bakery, brewery, detergent, textile, paper and distilling industry (Ramachandran et al., 2004).

Alpha-amylase has been derived from several fungi, yeast, bacteria and actinomycetes; however, enzymes from fungi and bacteria sources have dominated applications in industrial sectors (Pandey et al., 2000). Evidences of amylase in yeast, moulds and bacteria have been reported and their properties documented (Buzzini and
Martini, 2002; Oyeleke and Oduwole, 2009). For industrial applications, enzymes must be stable under process conditions. Therefore, thermophilic microorganisms are believed to be potentially good alternative sources of thermostable enzymes (Egas et al., 1998).

However, the cost of producing this enzyme is high and the cost of procurement by developing countries can be even higher as a result of importation. Cheap and readily available agricultural waste such as potato peels, which presently constitutes a menace to solid waste management, may be a rich source of amylolytic bacteria (Ali et al., 1998). Alpha-amylase can be produced by different species of microorganisms, but for commercial applications $\alpha$ amylase is mainly derived from the genus Bacillus. Alpha amylases produced from Bacillus licheniformis, Bacillus stearothermophilus, and Bacillus amyloliquefaciens find potential application in a number of industrial processes such as in food, fermentation, textiles and paper industries (Konsoula and Liakopoulou-Kyriakides, 2007; Pandey et al., 2000). Bacillus subtilis, Bacillus stearothermophilus, Bacillus licheniformis, and Bacillus amyloliquefaciens are known to be good producers of thermostable $\alpha$-amylase, and these have been widely used for commercial production of the enzyme for various applications (Prakash and Jaiswal, 2009).

\section{Methods}

\subsection{Collection of samples and isolation}


The samples were collected from four different refuse dumps along Ede road and on Obafemi Awolowo University Campus, Ile-Ife, Nigeria at a depth of $30 \mathrm{~cm}$ with temperature of $45^{\circ} \mathrm{C}$. One gramme $(1 \mathrm{~g})$ of the decayed refuse material was serially diluted One millilitre $(1 \mathrm{ml})$ of the resulting dilution factors was pipetted into sterile Petri dish to which sterile nutrient agar was dispensed. The Petri dishes were incubated invertedly at $45^{\circ} \mathrm{C}$ for $24 \mathrm{~h}$ and examined for colony growth. Discrete colonies were picked and purified on sterile nutrient agar plates using the streak method The pure colonies were sub-cultured into sterile agar slants and kept in the refrigerator at $4^{\circ} \mathrm{C}$ at the Department of Microbiology laboratory, Obafemi Awolowo University, Ile-Ife, Osun State, Nigeria.

\subsection{Identification of isolates}

Bacteria isolates were identified using the Bergey's Manual of Determinative Bacteriology (Holt et al., 1994). Bacterial isolates were characterized by colonial, morphological and physiological characteristics through biochemical tests. This was followed by $16 \mathrm{~S}$ rRNA gene sequencing of the bacterium with the highest enzyme activity.

\subsection{S rRNA gene sequencing}

Extraction of DNA was done using CTAB method, the 16S rRNA gene was amplified by PCR using universal primer for bacteria: $16 \mathrm{~S}$ forward, 5'-GAGTTTGATATGTACTGGCTCAG, reverse, 5'-GAAGGAGGTGACCTCCACTGCC. The amplified 16S rRNA gene PCR products (gene fragment of $1000 \mathrm{bp}$ length) from this isolate, after purification by $2 \mathrm{M}$ Sodium acetate wash techniques was directly sequenced on the Gene Sequencer (ABI machine) - Macrogen USA. The 16S rRNA gene fragment (1000 bp length) sequenced in both direction to obtain gene sequence in the form of A, C, T and G was then blasted on http://ncbi.nlm.nih.gov to assess the DNA similarities.

\subsection{Methods for extraction of the raw starches}

Sorghum, yam, cassava, corn starches were extracted by using the method of Singh et al. (2009); Walter et al. (2000); Gunorubon (2012); Moorthy (1991) respectively; and production of cassava flour was carried out by established protocol.

\subsection{Alpha amylase production and extraction}

The enzyme production was carried out in $250 \mathrm{ml}$ Erlenmeyer flask containing $100 \mathrm{ml}$ medium using $1 \mathrm{ml} 0.5 \mathrm{McF}$ arland standard inoculum. The modified medium of Femi-Ola and Olowe (2011) was made up of $1 \mathrm{~g}$ soluble starch, $0.1 \mathrm{~g} \mathrm{KH}_{2} \mathrm{PO}_{4}, 0.25 \mathrm{~g}$ $\mathrm{Na}_{2} \mathrm{HPO}_{4}, 0.1 \mathrm{~g} \mathrm{NaCl}, 0.005 \mathrm{~g} \mathrm{MgSO}_{4} .7 \mathrm{H}_{2} \mathrm{O}, 0.005 \mathrm{~g}, \mathrm{CaCl}_{2}, 0.2 \mathrm{~g}$ (NH4) ${ }_{2} \mathrm{SO}_{4}$ and $0.2 \mathrm{~g}$ peptone; at $\mathrm{pH}$ 7.0. The medium was inoculated with the standard inoculum and incubated at $45^{\circ} \mathrm{C}$ for $48 \mathrm{~h}$ with a steady agitation at $150 \mathrm{rpm}$. This was centrifuged at 6000 rpm for $30 \mathrm{~min}$ to obtain the cell-free supernatant (CFS), the enzyme activity was determined by Nelson (1944) and Somogyi (1945) methods; and the protein concentration was quantified by Bradford method (1976) using $10 \mathrm{mM}$ phosphate buffer at $\mathrm{pH} 7$.

\subsection{Optimization of alpha amylase production}

The optimum $\mathrm{pH}(4.5-8.5)$, temperature $\left(35^{\circ} \mathrm{C}-60^{\circ} \mathrm{C}\right)$, percentage soluble starch composition $(0.5-2.5 \%)$, different carbon and nitrogen sources for the production of $\alpha$-amylase was determined with $0.5 \mathrm{ml}$ inocula size in $50 \mathrm{ml}$ of the basal medium and agitation at $150 \mathrm{rpm}$ in an incubator shaker. The cell-free supernatant obtained was assayed for $\alpha$-amylase activity.

\subsection{Growth and enzyme production}

The growth curve and enzyme production for Bacillus sp. RD24 was determined by inoculating a $250 \mathrm{ml}$ enzyme production medium with $10 \mathrm{ml}$ standard inoculum of $0.5 \mathrm{McF}$ arland standards in an Erlenmeyer flask. This was incubated at $45^{\circ} \mathrm{C}$ for $48 \mathrm{~h}$ with agitation at $150 \mathrm{rpm}$. At $2 \mathrm{~h}$ interval, $5 \mathrm{ml}$ samples were collected aseptically for a period of $48 \mathrm{~h}$. The turbidity of the culture was checked at $680 \mathrm{~nm}$ using Spectrumlab 23A spectrophotometer and recorded as the cell optical density. The enzyme activity of each sample supernatant was assayed using the method stated above.

\subsection{Effect of Some Raw Starchy Sources on Enzyme Production}

Some raw starch sources namely yam, millet, cassava flour, corn starch and cassava starch were used to replace the soluble starch in the enzyme production media $(50 \mathrm{ml})$ while other media components were kept constant. These were inoculated with $0.5 \mathrm{ml}$ of the standardized inoculum of Bacillus sp. RD24 and incubated at $45^{\circ} \mathrm{C}$ for $48 \mathrm{~h}$ with $150 \mathrm{rpm}$ agitation. The cell-free supernatant obtained was assayed for $\alpha$-amylase activity and protein concentration as stated above.

\section{Results}

\subsection{Thermophilic amylolytic bacteria}

The isolated and identified bacteria were Bacillus alvei (40\%) Bacillus licheniformis (40\%) and Bacillus brevis (20\%) as presented in Table 1. The result of the blasting of Bacillus licheniformis RD24 gene sequence revealed $91 \%$ maximum identity.

\subsection{Growth and Alpha Amylase Production}

Amylase production was evident in the culture supernatant at about $8 \mathrm{~h}$ of incubation with $17.43 \mathrm{Units} / \mathrm{ml} \alpha$-amylase activity, the lag phase for a period of $4 \mathrm{~h}$ was observed. The peak of amylase production was at $20 \mathrm{~h}$ of incubation which is $925.19 \mathrm{Units} / \mathrm{ml}$ (Fig. 1). Though $\alpha$-amylase activity reduced after a period of $48 \mathrm{~h}$, it did not result in total loss of activity.

\subsection{Optimum $\mathrm{pH}$ and temperature for alpha amylase production by Bacillus licheniformis RD24}

The optimum $\mathrm{pH}$ and temperature for the production of alpha amylase in the culture condition are 7.0 and $45^{\circ} \mathrm{C}$ with $150 \pm 0.8$ Units $/ \mathrm{ml}$ and $58.1 \pm 2.4$ Units $/ \mathrm{ml}$ respectively as presented in Fig. 2 and 3.

3.4. Effect of percentage starch composition, nitrogen, carbon sources and raw starches on the production of alpha amylase by Bacillus licheniformis RD24

The highest amylase activity was recorded with $1.5 \%$ starch as $102.3 \pm 7.5$ Units/ml (Fig. 4). The most suitable nitrogen source for the production of $\alpha$-amylase was discovered to be peptone with enzyme activity of $165 \pm 12.7$ Units/ml followed by yeast extracts, $\left(\mathrm{NH}_{4}\right)_{2} \mathrm{SO}_{4}$ and calcium nitrate with $52.3 \pm 4$ Units $/ \mathrm{ml}, 41.2 \pm 0.01$ Units/ml and $32.21 \pm 4.99$ Units $/ \mathrm{ml}$ respectively (Fig. 5).

The production of $\alpha$-amylase was discovered to be highest (32.9 \pm 7 Units $/ \mathrm{ml}$ ) with starch as the sole carbon source in relation to maltose, glucose, melibiose, lactose and maltose (Fig. 6).

The use of raw starch such as cassava flour, cassava, yam, millet and corn starches respectively as a carbon source for the production of $\alpha$-amylase gave an appreciable specific activity. Cassava flour gave the highest specific activity of $72.12 \pm 0.09$ Units/ mg protein followed by cassava starch $22.83 \pm 1.30 \mathrm{Units} / \mathrm{mg}$ protein as shown in Fig. 7. 
Table 1: Gram's Staining, Spore Staining and Biochemical Characteristics of the Isolates

\begin{tabular}{|c|c|c|c|c|c|}
\hline $\begin{array}{l}\text { Isolate } \\
\text { Code }\end{array}$ & RD 13 & RD 24 & RD 18 & RD 22 & RD 14 \\
\hline Gram Reaction & + & + & + & + & + \\
\hline Shape & Rod & Rod & Rod & Rod & Rod \\
\hline Catalase & + & + & - & + & + \\
\hline Starch hydrolysis & + & + & + & + & + \\
\hline Citrate & - & - & + & + & - \\
\hline Spore staining & + & + & + & + & + \\
\hline Melibiose & A & - & - & - & A \\
\hline Glucose & A & - & A & - & A \\
\hline Mannitol & - & - & A & - & - \\
\hline Rhamnose & - & - & - & - & - \\
\hline Galactose & - & - & - & - & + \\
\hline Xylose & - & - & - & - & A \\
\hline Lactose & - & - & - & - & + \\
\hline Arabinose & - & A & NT & NT & A \\
\hline Methyl Red & + & - & - & - & - \\
\hline VogesProskauer & + & + & - & + & + \\
\hline $6.5 \% \mathrm{NaCl}$ & + & + & + & + & + \\
\hline $\mathrm{NO}_{3}$ Reduction & + gas & + gas & + gas & + gas & + gas \\
\hline $\mathrm{O} / \mathrm{F}$ & OX & $\mathrm{F}$ & $\mathrm{F}$ & $\mathrm{F} / \mathrm{OX}$ & $\mathrm{OX}$ \\
\hline $\mathrm{H}_{2} \mathrm{~S}$ Production & - & + & - & - & - \\
\hline Indole test & - & - & - & - & - \\
\hline Motility test & - & + & + & + & - \\
\hline Growth@55 ${ }^{\circ} \mathrm{C}$ & - & - & + & + & - \\
\hline Urease test & - & + & + & + & - \\
\hline Gelatin hydrolysis & + & + & + & + & + \\
\hline Probable bacterium & Bacillus alvei & Bacillus licheniformis & Bacillus brevis & Bacillus licheniformis & Bacillus alvei \\
\hline
\end{tabular}

Key: + = Positive, - = Negative, $\mathrm{OX}=$ Oxidative, $\mathrm{F}=$ Fermentative, $\mathrm{NT}=$ Not tested, $\mathrm{NA}=\mathrm{Not}$ applicable, $\mathrm{H}_{2} \mathrm{~S}=\mathrm{Hydrogen}_{\mathrm{H}}$ sulphide, $\mathrm{NO}_{3}=\mathrm{Nitrate}, \mathrm{NaCl}$ $=$ Sodium chloride.

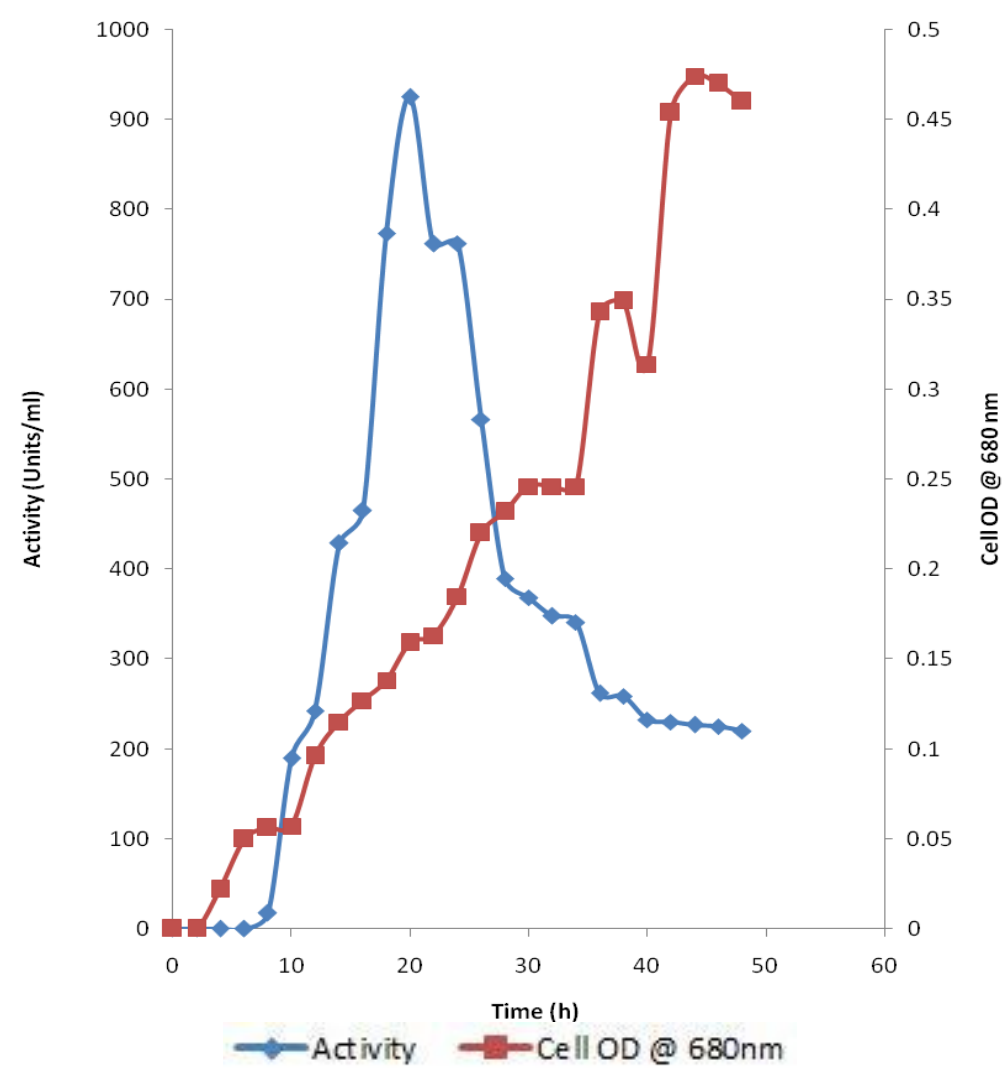

Fig. 1: Growth and Enzyme Production Curve at $45^{\circ} \mathrm{C}$ and $\mathrm{pH}$ for $48 \mathrm{H}$. 


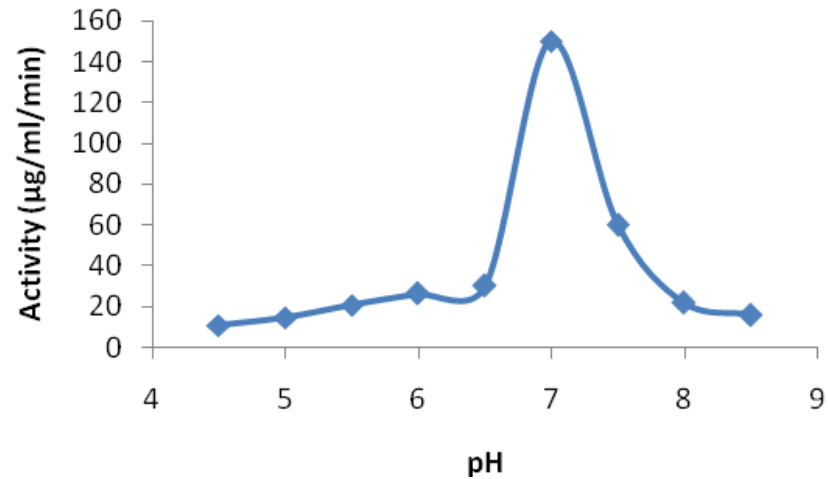

Fig. 2: Effect of $\mathrm{PH}$ on the Production of Bacillus licheniformis RD24 Crude a-Amylase

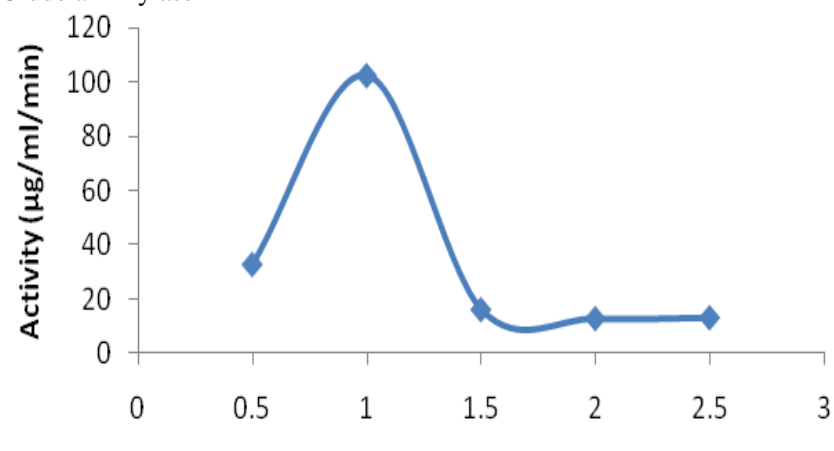

Percentage starch composition (\%)

Fig. 4: Effect of Percentage (\%) Starch Composition on the Production of Bacillus licheniformis RD24 Crude an Amylase.

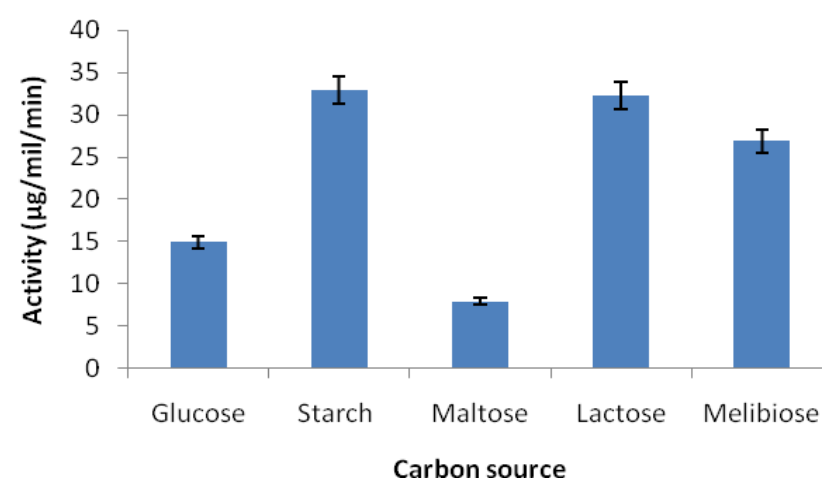

Fig. 6: Effect of Carbon Source on Bacillus licheniformis RD24 Crude aAmylase Production

\section{Discussion}

The isolation of the thermophilic bacteria from the dumpsite in the study location with amylolytic properties is a prove of the fact that decay of food waste in such dumpsite is not just the function of chemical and physical changes at the site but also as a result of biological activities brought about by bacteria and other microorganisms. The growth and survival of the thermophilic bacteria can be said to be due to active decomposition of waste which involves release of energy, and therefore select for those that can adapt to high temperature. This is in accordance with the work of Ajayi and Fagade (2006); Adeniran and Abiose (2011) and Aynadis et al. (2013). The bacterium with the highest amylase activity subjected to molecular characterization by $16 \mathrm{~S}$ rRNA gene sequencing and identified as Bacillus licheniformis RD24 with a maximum identity of $91 \%$ to other Bacillus licheniformis is a clear indication that if biochemical characterization is improved upon, it will be very useful in identifying bacterial isolates; though still strongly dependent on molecular characterization for confirmation.

Production of $\alpha$-amylase by Bacillus species is often dependent on growth of the bacterium in the appropriate media composition. It was observed in Bacillus licheniformis RD24 that peak of amylase

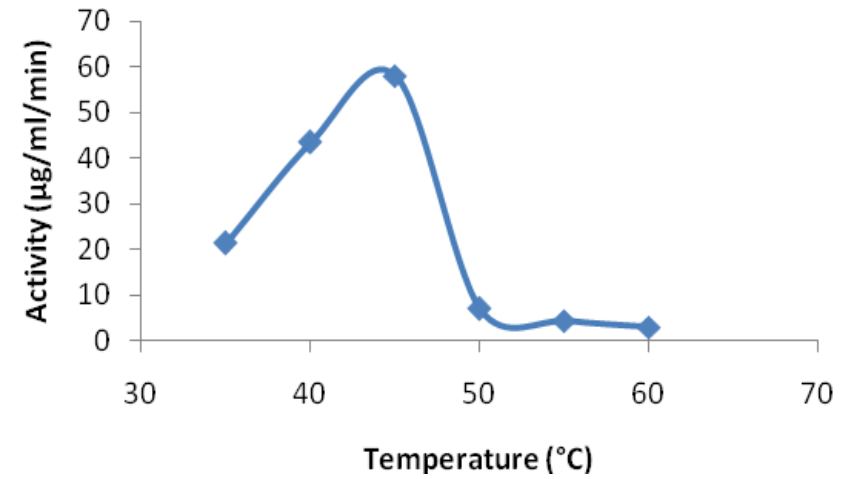

Fig. 3: Effect of Temperature on the Production of Bacillus licheniformis RD24 Crude a-Amylase.

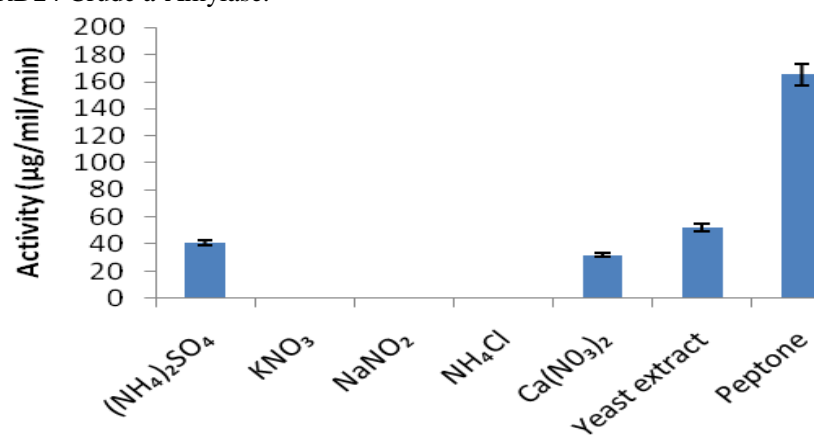

Nitrogen source

Fig. 5: Effect of Nitrogen Source on the Production of Bacillus licheniformis RD24 Crude a-Amylase.

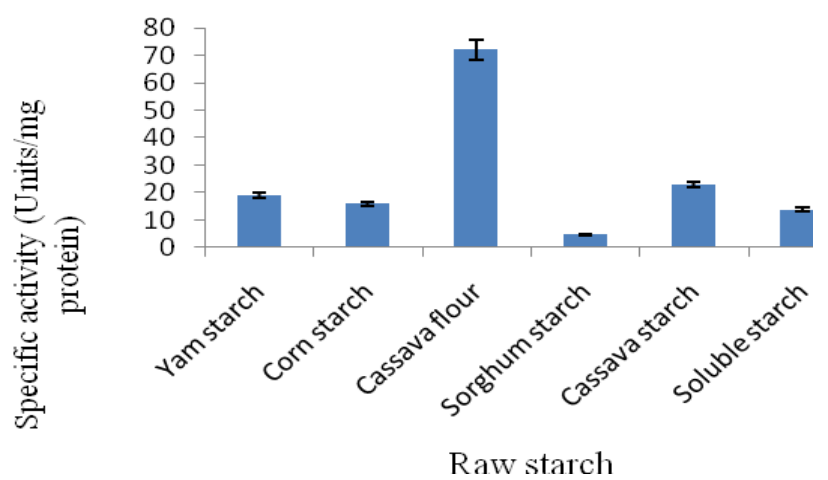

Fig. 7: Effect of Raw Starches on Bacillus licheniformis RD24 Crude aAmylase Production

production was at $20 \mathrm{~h}$ with gradual decline even when it seems the growth of the bacterium persisted (Fig. 1). The decline in amylase production may be due to exhaustion of the nutrients or accumulation of other products or metabolites which may be inhibitory to the growth of the bacterium and amylase production as noted by Prakash et al. (2009).

The optimum $\mathrm{pH}$ is in accordance with the results of some researchers who had reported $\mathrm{pH} 7$ for alpha amylase production by species of Bacillus (Oyeleke et al., 2010; Mohammed et al., 2011). A wide range of temperature $\left(35-80^{\circ} \mathrm{C}\right)$ has been reported for optimum growth and $\alpha$-amylase production in bacteria (Burhan et al., 2003; Prakash et al., 2009). However, in this study, the optimum temperature for the production of $\alpha$-amylase was observed to be $45^{\circ} \mathrm{C}$ which confirms it as thermophilic in nature. This result agreed with the investigation of Mohammed et al. (2011); Aynadis et al. (2013) and Yasser et al. (2013) but is slightly better than $42{ }^{\circ} \mathrm{C}$ reported by Deb et al. (2013).

The findings of this study are a clear indication that though hydrolysis of starch may occur at different percentage starch composition of the medium, $1 \%$ is the most suitable. This is closely related to the findings of Mohammed et al. (2011) who observed maximum enzyme activity in the range of 1 to $1.5 \%$ of starch concentration and Yasser et al. (2013) who reported inhibition in the $\alpha$-amylase activity beyond starch percentage concentration of 
$1.25 \%$. The result obtained from the various nitrogen sources investigated may be due to the fact that peptone may be readily available to the bacterium for metabolism during growth and enzyme production as opposed to yeast extract. Other inorganic nitrogen sources such as $\mathrm{KNO}_{3}, \mathrm{NaNO}_{3}$ and $\mathrm{NH}_{4} \mathrm{Cl}$ investigated in this study only supported the growth of the bacterium but not enzyme synthesis.

The outcome of the study on variation of carbon sources for the production of $\alpha$-amylase is contrary to Dilli et al. (2006) who reported that Bacillus subtilis KCC103 secreted amylase with glucose as the major carbon source.

Of the raw starches tested as carbon sources, the high specific activity of cassava flour may be due to the presence of other metabolites in the material which can stimulate the synthesis of amylase, because cassava flour is a product of microbial transformation. Ajayi and Fagade (2006) reported that Bacillus species are better on corn starch than soluble starch. Similarly, Ruban et al. (2013) also reported that amylase production by low-grade cheap impure substrate sago waste and wheat bran produced very high amount of amylase than soluble starch by Bacillus subtilis and Aspergillus niger. These are in accordance with the report of this study as four out of the five carbon sources resulted in better specific activity than the soluble starch.

\section{Conclusion}

In conclusion, this study revealed that Bacillus licheniformis RD24 had a unique characteristic of thermostability and the ability to hydrolyze cheap raw starches for the production of $\alpha$-amylase Starch-rich household waste can therefore be converted for amylase production instead of constituting public nuisance.

\section{Acknowledgement}

The authors wish to appreciate Mr. Oyelakin and all the members of Staff of the Biotechnology Centre, Federal University of Agriculture, Abeokuta (FUNAAB), and Nigeria for the molecular characterization of the bacterium.

\section{References}

[1] Adeniran HA, \& Abiose SH (2011) Partial purification, characterization and hydrolytic activities of amylases from Bacillus licheniformis and Aspergillus niger cultured on agricultural residues. African Journal of Biotechnology 11(6), 1465-1477.

[2] Ajayi AO \& Fagade OE (2006) Growth pattern and structural nature of amylases produced by some Bacillus species in starchy substrates. African Journal of Biotechnology 5(5), 440-444.

[3] Ali S, Mahmood S, Alan R \& Hossain Z (1998) Culture Condition for Production of glucoamylase from rice bran by Aspergillus terreus. MIRCEN Journal of Applied Microbiology and Biotechnology 5, 525-532. http://dx.doi.org/10.1007/BF01741829.

[4] Asgher M, Asad MJ, Rehman SU \& Legge RL (2007) thermostable alpha amylase from a moderately thermophilic Bacillus subtilis strains for starch processing. Journal of Food Engineering 79, 950-955. http://dx.doi.org/10.1016/j.jfoodeng.2005.12.053.

[5] Aynadis TH, Tilahun BG \& Gulelat DH (2013) Thermostable alpha-amylase from geothermal sites of Ethiopia (Afar Region) Isolation, purification and characterization. Greener Journal of Biological Sciences 3(2), 061-073.

[6] Babu KR \& Satyanarayana T (1993) Extracellular calcium inhibited $\alpha$-amylase production in a batch and fed batch culture of Bacillus subtilis. Folia Microbiological 29, 359-364.

[7] Bradford MM (1976) A rapid and sensitive method for the quantification of microgram quantities of proteins, utilizing the principle of protein-dye binding. Analytical Biochemistry 72, 248-254. http://dx.doi.org/10.1016/0003-2697 (76)90527-3.

[8] Burhan A, Nisa U, Gokhan C, Omer C, Ashabil a \& Osman G (2003) Enzymatic properties of a novel thermophilic, alkaline and chelator resistant amylase from an alkalophilic Bacillus sp. isolate ANT-6. Process Biochemistry 38, 1397-1403. http://dx.doi.org/10.1016/S0032-9592 (03)00037-2.
[9] Buzzini P \& Martini a (2002) Extracellular enzymatic activity profiles inyeast and yeast-like strains isolated from tropical environments. Journal of Applied Microbiology 93, 1020-1025. http://dx.doi.org/10.1046/j.1365-2672.2002.01783.x.

[10] Deb P, Talukdar SA, Mohsina K, Sarker PK \& Sayem SMA (2013) Production and partial characterization of extracellular amylase enzyme from Bacillus amyloliquefaciens P-001. Springerplus 2, 154. http://dx.doi.org/10.1186/2193-1801-2-154.

[11] Dilli RN, Rajagopalan G \& Krishnan C (2006) Purification and characterization of a maltooligosaccharide-forming $\alpha$-amylase from a new Bacillus subtilis KCC103. Applied Microbiology and Biotechnology 73,3 .

[12] Egas MCV, Costa MS, Cowan DA \& Pires EMV (1998) Extracellular $\alpha$-amylase from Thermus filiformis Ork A2: Purification and biochemical characterization. Extremophiles 2, 23-32. http://dx.doi.org/10.1007/s007920050039.

[13] Femi-Ola TO \& Olowe BM (2011) Characterization of alpha amylase from Bacillus subtilis BS5 isolated from Amitermes evuncifer Silvestri. Research Journal of Microbiology 6(2), 140-146. http://dx.doi.org/10.3923/jm.2011.140.146.

[14] Gunorubon AJ (2012) Production of cassava starch-based adhesive. Research Journal in Engineering and Applied Sciences 1(4), 219214.

[15] Holt JG, Kneg NR, Sneath PHA, Stanly JT \& Williams ST (1994) Bergeys Manual of Determinative Bacteriology, ninth Edition, Williams and Wilkins, Baltimore.

[16] Konsoula Z \& Liakopoulou-Kyriakides M (2007) Co-production of alpha-amylase and beta-galactosidase by Bacillus subtilis in complex organic substrates. Bioresource Technology 98, 150-157. http://dx.doi.org/10.1016/j.biortech.2005.11.001.

[17] Mohammed MAA-Z, Shivayogeeshwar N, Gurumurthy DM \& Rajeshwara AN (2011) Identification, characterization of novel halophilic Bacillus cereus Ms6: a source for extra cellular $\alpha$ amylase. Advances in Environmental Biology 5(5), 992-999.

[18] Moorthy SN (1991) Extraction of starches from tuber crops using ammonia. Carbohydrate Polymer 16, 391-398. http://dx.doi.org/10.1016/0144-8617 (91)90057-J.

[19] Nelson N (1944) A phytometric adaption of the somogyi method for the determination of glucose. Journal of Biological Chemistry $153,373-380$

[20] Oyeleke SB \& Oduwole AA (2009) Production of amylase by bacteria isolated from a cassava waste dumpsite in Minna, Niger State, Nigeria. African Journal of Microbiology Research 3(4), $143-146$

[21] Oyeleke SB, Auta SH \& Egwim EC (2010) Production and characterization of amylase produced by Bacillus megaterium isolated from a local yam peel dumpsite in Minna, Niger State. Journal of Microbiology and Antimicrobials 2(7), 88-92.

[22] Pandey A, Nigam P, Soccol CR, Soccol VT, Singh D \& Mohan R (2000) Advances in microbial amylases, Biotechnology and Applied Biochemistry 31(2), 135-152. http://dx.doi.org/10.1042/BA19990073.

[23] Prakash B, Vidyasagar M, Madhukumar MS, Muralikrishna G \& Sreeramulu K (2009) Production, purification and characterization of two extremely halotolerant, thermostable, and alkali-stable $\alpha$ amylases from Chromohalobacter sp. TVSP 101. Process Biochemistry 44 , http://dx.doi.org/10.1016/j.procbio.2008.10.013.

[24] Prakash O \& Jaiswal N (2009) Alpha-Amylase: An Ideal Representative of Thermostable Enzymes. Applied Biochemistry and Biotechnology $160,2401-2414$. http://dx.doi.org/10.1007/s12010009-8735-4

[25] Ramachandran S, Patel AK., Nampaorhiri KM, Francis F, Nagy V, Szakacs G \& Pandey A (2004) Coconut oil cake - A potential raw material for the production of $\alpha$-amylase. Bioresourse Technology 93, 169-174. http://dx.doi.org/10.1016/j.biortech.2003.10.021.

[26] Ruban P, Sangeetha T \& Indira S (2013) Starch waste as a substrate for amylase production by Sago effluent isolates Bacillus subtilis and Aspergillus niger. American-Eurasian Journal Agricultural and Environmental Science 13(1), 27-31.

[27] Sarikaya E, Higasa T, Adachi M \& Mikami B (2000) Comparison of degradation abilities of $\beta$ - and $\alpha$-amylases on raw starch granules. Process Biochemistry 35 711-715. http://dx.doi.org/10.1016/S0032-9592 (99)00133-8.

[28] [28] Singh H, Singh SN \& Singh N (2009) Structure and functional properties of acid thinned sorghum starch. International Journal of Food Properties 12, 713-725. http://dx.doi.org/10.1080/10942910801995614

[29] Somogyi M (1945) A new reagent for the determination of sugars. Journal of Biological Chemistry 160, 61-68. 
[30] [30] Walter WM, Truong VD, Wiesenborn DP \& Carvajal P (2000) Rheological and physico-chemical properties of starches from moist- and dry-type sweet potatoes. Journal of Agriculture,
Food
$\&$
Chemistry
48 ,
2937-2942

http://dx.doi.org/10.1021/jf9909631

[31] Yasser RA-F, Soliman NA, El-Toukhy NM, El-Gendi H \& Ahmed R S (2013) Production, purification, and characterization of thermostable $\alpha$-amylase produced by Bacillus licheniformis Isolate AI20. Journal of Chemistry Volume 2013, Article ID 673173, 11 pages. http://dx.doi.org/10.1155/2013/673173. 